\title{
STUDY ON STRENGTH OF CONCRETE BY USING RECYCLED AGGREGATE FROM DEMOLITION WASTE IN CONCRETE
}

\author{
Arul Gideon.R ${ }^{1}$, Vidhya Lakshmi.A ${ }^{2}$, Karthikeyan.K ${ }^{\mathbf{3}}$, Uthayakumar.P ${ }^{\mathbf{4}}$ \\ ${ }^{1,2,3,4}$ PG Student, Department of Civil Engineering, Sree Sastha Institute of Engineering and Technology, \\ Chembarambakkam, Chennai, TamilNadu-600123.
}

\begin{abstract}
Concrete waste is generated whenever any demolition activities take place. Among various types of demolished waste materials, concrete waste accounts for about $50 \%$ of the total waste generated. The current practice of dumping construction waste materials for land filling affects the groundwater recharges and land degradation. Recycling concrete waste as recycled aggregate is one of the methods adopted to reduce the environmental impact. The aim of this study is to know the feasibility of using concrete waste as coarse aggregate for making new concrete. Metal coarse aggregate is replaced by recycled coarse aggregate by weight in M25 grade concrete. The Recycled Aggregate Concrete (RAC) specimens were tested for compressive strength, tensile strength and flexural strength and results obtained are compared with the conventional Concrete.
\end{abstract}

Keywords: Recycled Coarse Aggregate, Recycled Aggregate Concrete, Polypropylene Fibre, Coir Fibre, Silica Fume. ****.

\section{INTRODUCTION}

The environment should be protected from the hazard of getting polluted which is the real sustainable development. At present, infrastructural development results in serious problem of construction and demolition waste disposal. At the same time there is a great demand for the natural aggregates (NA). There is no substituent product for natural aggregate. To full fill this demand as well as to conserve the land from concrete waste as landfills the only way is to use recycled aggregates from concrete waste. This process will result in reduction of demand on natural aggregates as well as the disposal of waste in land as landfills.

Recycled Aggregate (RA) is obtained from the demolition of buildings, flexible pavements etc. The Recycled Aggregate (RA) is used for producing fresh concrete and it is known as Recycled Aggregate Concrete (RAC). Due to infrastructural development and urbanization many old buildings are demolished which produce large quantity of Recycled Aggregate (RA).

\section{MATERIALS AND METHODS}

\subsection{Materials}

The materials used in this research work are ordinary Portland cement of 53 grade, river sand, coarse aggregate of $20 \mathrm{~mm}$ nominal size, recycled coarse aggregate of $20 \mathrm{~mm}$ nominal size, polypropylene fibre, natural (coir) fibre, Silica fume.

\subsection{Preparation of Specimens}

Concrete mix proportions of ratio 1:1:2 is used for the preparation of specimens. Conventional specimens were casted. Recycled aggregate specimens, Recycled aggregate specimen with polypropylene fibre and $10 \%$ silica fume,
Recycled aggregate specimen with natural(coir) fibre and $10 \%$ silica fume where the coarse aggregate is replaced by the recycled coarse aggregate from concrete waste of about $10 \%, 20 \%, 30 \%, 40 \%, 50 \%, 75 \%$ and $100 \%$ are also casted in parallel. The specimens were cured under tap water at room temperature and tested at the age of 7, 14 and 28days.

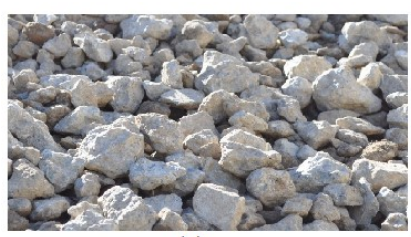

(a)

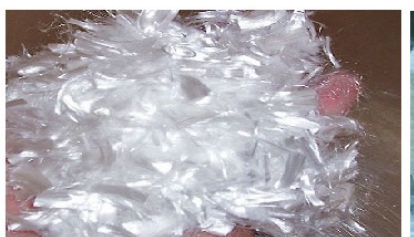

(c)

Fig -1: (a) Recycled aggregate (c) Polypropylene fibre

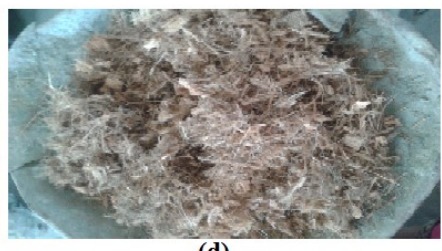

(d) (b) Silica fume

(d) Coir fibre

\section{TESTS ON CONCRETE}

\subsection{Compressive Strength Test}

The casted specimens of size $150 \mathrm{~mm} * 150 \mathrm{~mm} * 150 \mathrm{~mm}$ cubes were tested to determine the compressive strength at the age of 7, 14 and 28 days.

\subsection{Tensile Strength Test}

The casted specimens of size $150 \mathrm{~mm} * 300 \mathrm{~mm}$ cylinders were tested to determine the tensile strength at the age of 7 , 14 and 28days. 


\subsection{Flexural Strength Test}

The casted specimens of size $1 \mathrm{~m} * 0.15 \mathrm{~m} * 0.15 \mathrm{~m}$ beams were tested to determine the flexural strength at the age of 28days.

\section{RESULTS AND DISCUSSION}

The various results obtained from the compressive strength tests, tensile strength tests and flexural strength tests were discussed and tabulated. The charts representing the test results were also provided. The table 1,4 and 7 indicates the results of the compressive strength, tensile strength and flexural strength of the RCA concrete whereas the table 2, 3, 5 and 6 indicates the results of the compressive strength tensile strength, flexural strength of the RCA concrete with polypropylene fibre and natural fibre (coir) respectively.

Table -1: Compressive strength of RCA concrete

\begin{tabular}{|c|c|c|c|}
\hline \multirow{2}{*}{$\begin{array}{c}\text { \% of } \\
\text { RCA }\end{array}$} & \multicolumn{3}{|c|}{ Compressive strength of RCA concrete } \\
N/.mm
\end{tabular}

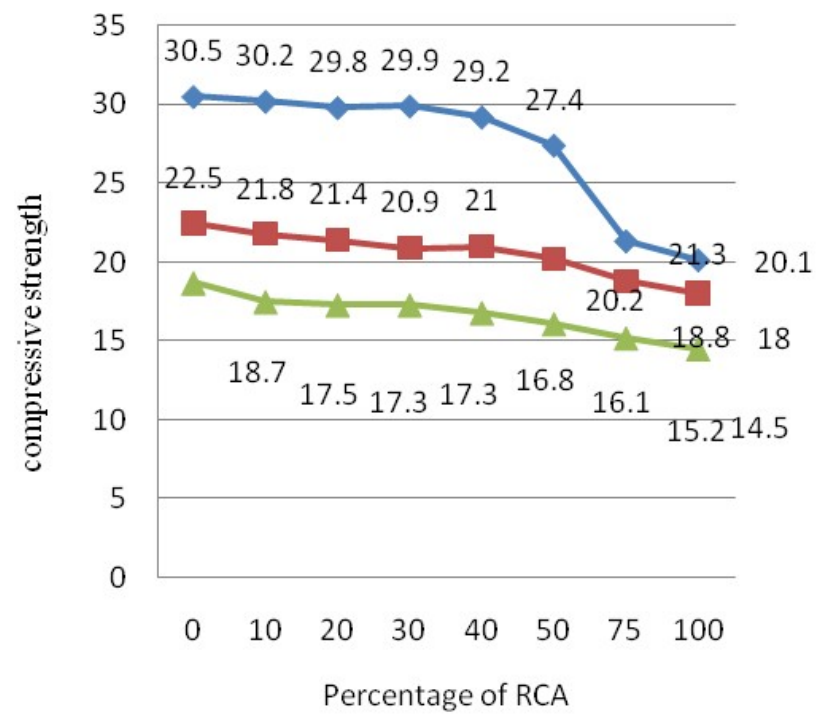

$\multimap 28$ Days $\neg-14$ Days $\longrightarrow 7$ Days

Chart -1: Compressive strength of RCA concrete
Table -2: Compressive Strength of RCA Concrete with Polypropylene Fibre and 10\% Silica Fume

\begin{tabular}{|c|c|c|c|}
\hline \multirow{2}{*}{$\begin{array}{c}\text { \% of } \\
\text { RCA }\end{array}$} & \multicolumn{3}{|c|}{$\begin{array}{c}\text { Compressive Strength of RCA Concrete } \\
\text { with Polypropylene Fibre and 10\% Silica } \\
\text { Fume N/mm }\end{array}$} \\
\cline { 2 - 4 } & 7 Days & 14 Days & 28 Days \\
\hline 0 & 21.2 & 37.4 & 45.5 \\
\hline 10 & 20.8 & 35.65 & 43.9 \\
\hline 20 & 19.8 & 34.82 & 42.32 \\
\hline 30 & 19.2 & 35.24 & 43.86 \\
\hline 40 & 19.6 & 36.6 & 45.2 \\
\hline 50 & 19 & 33.9 & 43.6 \\
\hline 75 & 17.2 & 29.2 & 32.4 \\
\hline 100 & 16.8 & 27.8 & 28.8 \\
\hline
\end{tabular}

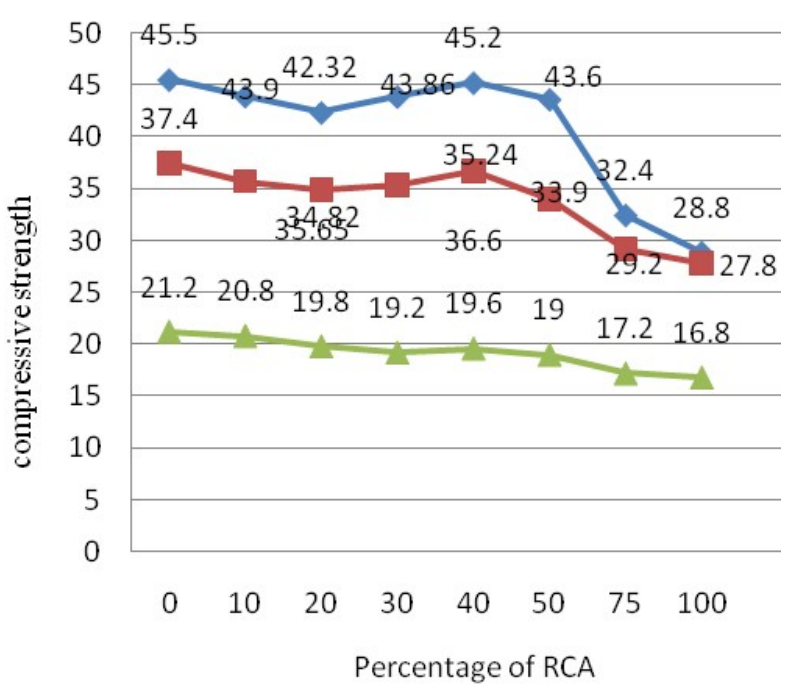

$$
\longrightarrow 28 \text { Days }-14 \text { Days }-7 \text { Days }
$$

Chart -2: Compressive Strength of RCA Concrete with Polypropylene Fibre and 10\% Silica Fume

Table -3: Compressive Strength of RCA Concrete with Natural Fibre (Coir) and 10\% Silica Fume

\begin{tabular}{|c|c|c|c|}
\hline \multirow[t]{2}{*}{$\begin{array}{l}\% \text { of } \\
\text { RCA }\end{array}$} & \multicolumn{3}{|c|}{$\begin{array}{l}\text { Compressive Strength of RCA Concrete } \\
\text { with Natural Fibre (Coir) And } 10 \% \text { Silica } \\
\text { Fume N/mm }\end{array}$} \\
\hline & 7 Days & 14 Days & 28 Days \\
\hline 0 & 21 & 36.8 & 45.26 \\
\hline 10 & 20.65 & 35.7 & 43.3 \\
\hline 20 & 19.2 & 34.2 & 42.85 \\
\hline 30 & 19 & 34.9 & 43.64 \\
\hline 40 & 19.4 & 35.2 & 45.32 \\
\hline 50 & 18.6 & 32.9 & 44.2 \\
\hline 75 & 17 & 29.2 & 31.1 \\
\hline 100 & 16.4 & 27.2 & 27.3 \\
\hline
\end{tabular}




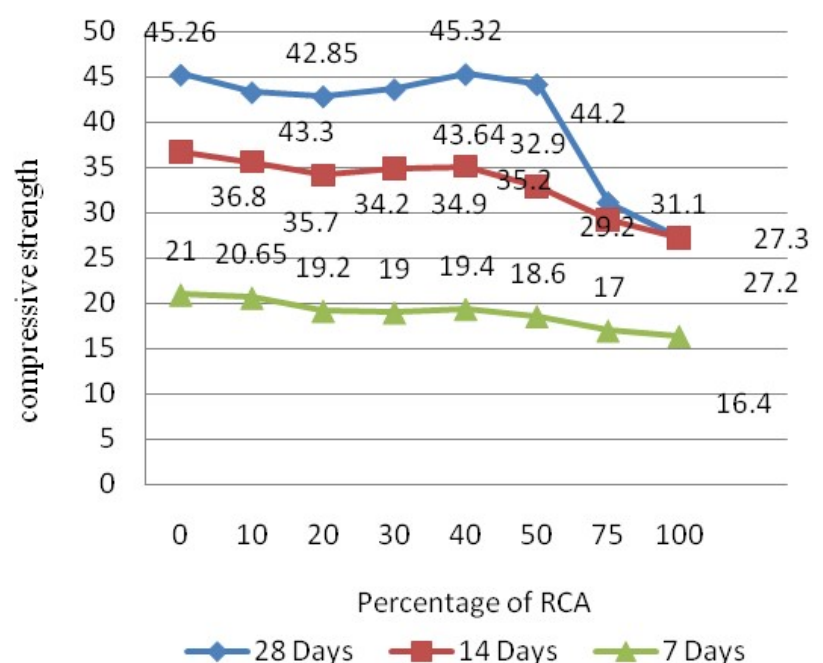

Chart -3: Compressive Strength of RCA Concrete with Natural Fibre (Coir) and 10\% Silica Fume

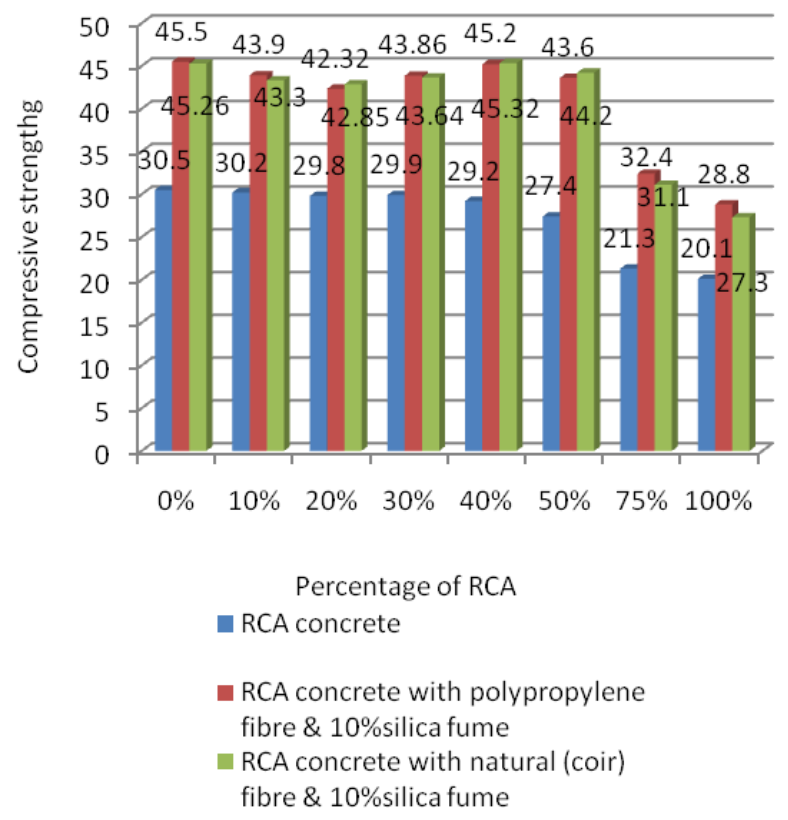

Chart -4: Comparison of Compressive Strength of RCA Concrete

Table -4: Tensile strength of RCA concrete

\begin{tabular}{|c|c|c|c|}
\hline \multirow{2}{*}{$\begin{array}{c}\text { \% of } \\
\text { RCA }\end{array}$} & \multicolumn{3}{|c|}{ Tensile strength of RCA concrete } \\
N/. mm & \\
\cline { 2 - 4 } & 7 Days & 14 Days & 28 Days \\
\hline 0 & 2.83 & 3.1 & 3.9 \\
\hline 10 & 2.6 & 3.15 & 3.7 \\
\hline 20 & 2.47 & 3.0 & 3.65 \\
\hline 30 & 2.34 & 2.9 & 3.5 \\
\hline 40 & 2.23 & 2.7 & 3.41 \\
\hline 50 & 2.15 & 2.56 & 3.24 \\
\hline 75 & 2 & 2.4 & 3.1 \\
\hline 100 & 1.89 & 2.1 & 2.8 \\
\hline
\end{tabular}

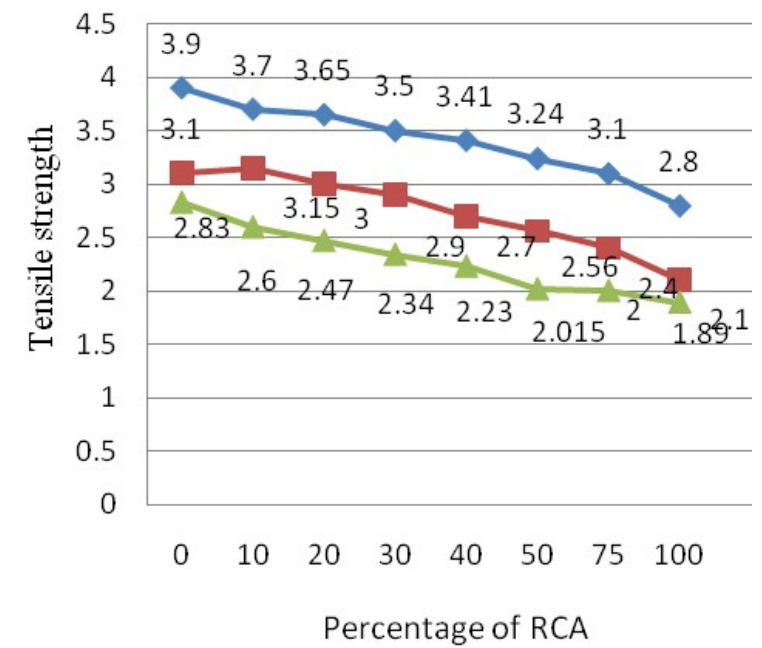

$\longrightarrow 28$ Days -14 Days $\rightarrow 7$ Days

Chart -5: Tensile strength of RCA concrete

Table -5: Tensile Strength of RCA Concrete with

Polypropylene Fibre and 10\% Silica Fume

\begin{tabular}{|c|c|c|c|}
\hline \multirow{2}{*}{\begin{tabular}{c}
\multirow{2}{*}{$\begin{array}{c}\text { RCA } \\
\text { RCA }\end{array}$} \\
\cline { 2 - 4 }
\end{tabular}} & \multicolumn{4}{|c|}{$\begin{array}{c}\text { Tensile Strength of RCA Concrete with } \\
\text { Polypropylene Fibre And 10\% Silica Fume } \\
\text { N/mm }\end{array}$} \\
\cline { 2 - 4 } & 7 Days & 14 Days & 28 Days \\
\hline 0 & 3.1 & 3.3 & 4.5 \\
\hline 10 & 2.9 & 3.45 & 4.8 \\
\hline 20 & 2.78 & 3.6 & 4.7 \\
\hline 30 & 2.6 & 3.9 & 4.8 \\
\hline 40 & 2.58 & 3.5 & 4.6 \\
\hline 50 & 2.1 & 2.38 & 3.3 \\
\hline 75 & 2.0 & 2.21 & 3.15 \\
\hline 100 & 1.9 & 2.0 & 2.9 \\
\hline
\end{tabular}

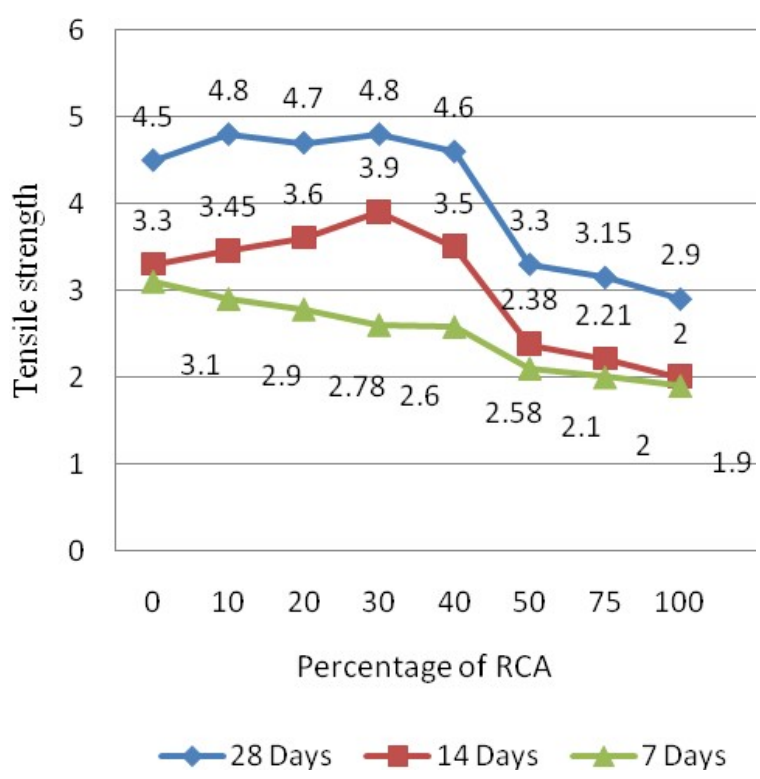

Chart -6: Tensile Strength of RCA Concrete with Polypropylene Fibre and 10\% Silica Fume 
Table -6: Tensile Strength of RCA Concrete with Natural Fibre (Coir) and 10\% Silica Fume

\begin{tabular}{|c|c|c|c|}
\hline \multirow[t]{2}{*}{$\begin{array}{l}\% \text { of } \\
\text { RCA }\end{array}$} & \multicolumn{3}{|c|}{$\begin{array}{c}\text { Tensile Strength of RCA Concrete with } \\
\text { Natural Fibre (Coir) and } 10 \% \text { Silica Fume } \\
\mathrm{N} / \mathrm{mm}^{2}\end{array}$} \\
\hline & 7 Days & 14 Days & 28 Days \\
\hline 0 & 3.0 & 3.38 & 4.4 \\
\hline 10 & 2.7 & 3.47 & 4.8 \\
\hline 20 & 2.65 & 3.5 & 4.6 \\
\hline 30 & 2.5 & 3.8 & 4.7 \\
\hline 40 & 2.51 & 3.6 & 4.5 \\
\hline 50 & 2.12 & 2.3 & 3.5 \\
\hline 75 & 2.0 & 2.24 & 3.1 \\
\hline 100 & 1.8 & 2.1 & 2.8 \\
\hline
\end{tabular}

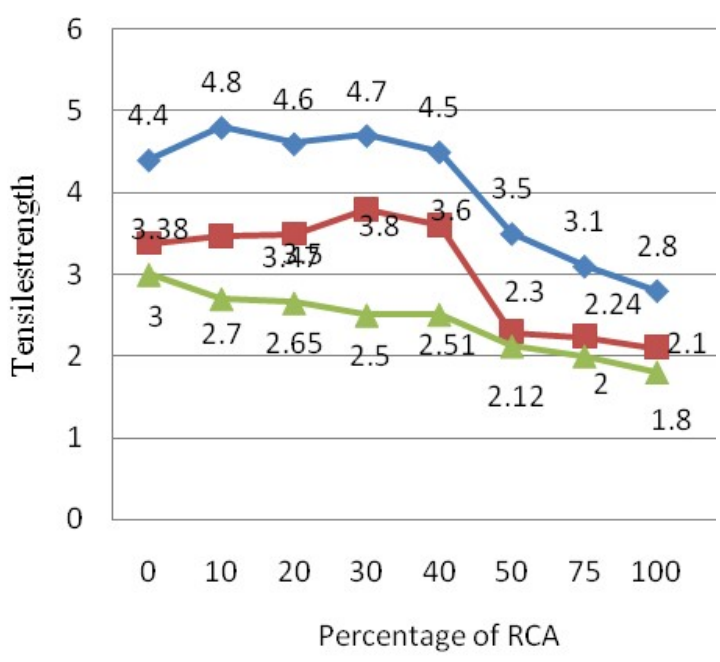

$\multimap 28$ Days -14 Days $\leftarrow-7$ Days

Chart -7: Tensile Strength of RCA Concrete with Natural Fibre (Coir) and 10\% Silica Fume

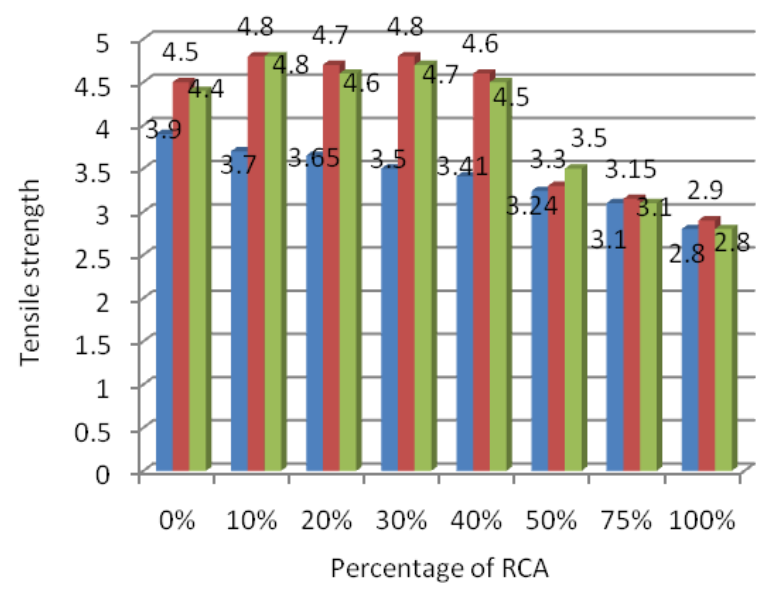

- RCA concrete

nCA concrete with polypropylene fibre \& $10 \%$ silica fume

RCA concrete with natural (coir) fibre \& $10 \%$ silica fume

Chart -8: Comparison of Tensile Strength of RCA Concrete
Table -7: Flexural strength of RCA concrete

\begin{tabular}{|c|c|c|c|}
\hline \multirow{2}{*}{\begin{tabular}{c} 
RCA \\
\cline { 2 - 4 }
\end{tabular}} & \multicolumn{3}{|c|}{ Flexural strength of RCA concrete MPa } \\
\cline { 2 - 4 } RCA & $\begin{array}{c}\text { RCA with } \\
\text { polypropylene } \\
\text { fibre and 10\% } \\
\text { silica fume }\end{array}$ & $\begin{array}{c}\text { RCA with } \\
\text { natural (coir) } \\
\text { fibre and 10\% } \\
\text { silica fume }\end{array}$ \\
\hline 0 & 4.56 & 6.48 & 6.45 \\
\hline 10 & 4.4 & 6.55 & 6.51 \\
\hline 20 & 4.63 & 6.38 & 6.29 \\
\hline 30 & 4.55 & 5.51 & 5.38 \\
\hline 40 & 4.57 & 4.85 & 4.81 \\
\hline 50 & 3.02 & 4.15 & 4.10 \\
\hline 75 & 2.85 & 3.96 & 3.82 \\
\hline 100 & 2.7 & 3.81 & 3.75 \\
\hline
\end{tabular}

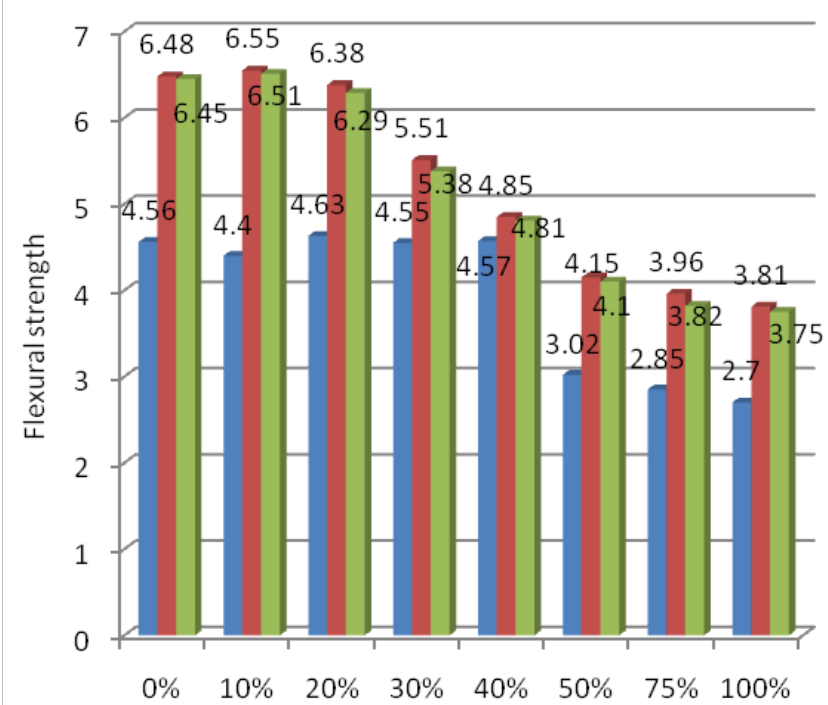

Percentage of RCA

RCA concrete
RCA concrete with polypropylene fibre \&
$10 \%$ silica fume
RCA concrete with natural (coir) fibre \&
$10 \%$ silica fume

Chart -9: Comparison of Flexural Strength of RCA Concrete

Based on the results obtained, it is found that

$>$ The workability was found to be in the decreasing order for RCA concrete. It may be due to the absorption of water by the recycled aggregate.

$>$ The compressive strength of concrete in which the coarse aggregate is replaced with RCA decreases when the percentage of RCA increases.

$>$ The split tensile strength of concrete decreases when the percentage of RCA in concrete increases.

$>$ The flexural strength of concrete in which the coarse aggregate was replaced by RCA decreases when the percentage of RCA in concrete increase. 
$>$ But at the same time, compressive strength, Split tensile strength and flexural strength was found to be considerably increased when compared with nominal and RCA concrete for RCA concrete added with polypropylene fibre and $10 \%$ of silica fume as a replacement of cement.

$>$ The compressive strength, Split tensile strength and flexural strength was also found to be considerably increased when compared with nominal and RCA concrete for RCA concrete added with natural (coir) fibre and $10 \%$ of silica fume as a replacement of cement.

$>$ The increase in compressive strength, Split tensile strength and flexural strength of RCA with polypropylene fibre and natural (coir) fibre respectively along with $10 \%$ replacement of cement with silica fume was only up to $40 \%$ replacement of CA with RCA more than that the results were falling.

$>$ Impact and Crushing values shows that the WCA shows considerable resistance against impact and gradual loads and these values are within the permissible limit to be used in the wearing surfaces.

\section{CONCLUSION}

From the discussion it is concluded that, the tests have been conducted for the prepared RCA and the results have been verified. The test results for the RCA and conventional concrete have been examined and compared. It is to be concluded that the compressive strength, split tensile strength and flexural strength are in the decreasing order when the percentage of RCA replacement increases. The compressive strength was found to be decreased by $10 \%$ for RCA. The split tensile strength was found to be decreased by $8 \%$ for RCA . The flexural was found to be decreased by $18 \%$ for RCA. The compressive strength, split tensile strength and flexural strength for RCA was more or less same compared to normal concrete when polypropylene fibre is added along with $10 \%$ replacement of cement by silica fume in RCA concrete. The compressive strength, split tensile strength and flexural strength for RCA was more or less same compared to normal concrete when natural (coir) fibre is added along with $10 \%$ replacement of cement by silica fume in RCA concrete. The increase in compressive tensile and flexural strength was noted till $40 \%$ replacement of RCA in concrete more than $40 \%$ result comes down. Before using the WCA it should be cleaned from the other materials carefully to get rid of debris. For larger structural work using WCA further study is required. Use of recycled aggregates in concrete provides a promising solution to the problem of C\&D waste management. In conclusion, up to $40 \%$ of WCA along with polypropylene fibre and natural (coir) fibre respectively with $10 \%$ replacement of cement by silica fume gives good results over compressive tensile and flexural strength. Recycling WCAs in concrete production may help solve a vital environmental issue apart from being a solution to the problem of inadequate concrete aggregates in concrete.

\section{REFERENCES}

[1] Aggregates for Concrete, Developed by American Concrete Institute (ACI) Committee E-701, First Printing August 2007.

[2] Cesar chan -"Use of recycled aggregate in shotcrete and concrete", published in University of British, Columbia - October 1998.

[3] Christian.J, Engelsen, Jacob Mehus, Claus Pade \& Dag Henning Saether. "Carbon dioxide uptake in demolished and crushed concrete", published in Norwegian Building Research Institute, 2005.

[4] Chemical-mineralogical characterisation of coarse recycled concrete aggregate M.C. Limbachiya , E. Marrocchino , A. Koulouris, Waste Management 27 (2007) 201-208.

[5] F. A. Mirza \& M. A. Saif "Mechanical properties of recycled aggregate concrete incorporating silica fume", in Proceedings of the 2nd International Conference on Sustainable Construction Materials and Technologies, Coventry University and The University of Wisconsin Milwaukee Centre for By-products Utilization, Ancona, Italy, June 2010.

[6] "Influence of amount of recycled coarse aggregates and production process on properties of recycled aggregate concrete" M. Etxeberria, E. Vázquez, A. Marí and M. Barra (2007), Cement and Concrete Research, Vol.37(5), pp.735-742.

[7] IS 12269:1987, Specification for 53 grades Ordinary Portland Cement, Bureau of Indian Standard, New Delhi.

[8] IS 3025:1964, Methods of sampling and test (physical and chemical) for water used in industry. IS 383:1970, "Specification for Coarse aggregate and Fine aggregate from Natural Sources for Concrete", Bureau of Indian Standard, New Delhi.

[9] "Local Construction And Demolition Waste Used As Coarse Aggregates In Concrete" Madan Mohan Reddy.K, Bhavani.R and Ajitha. B, International Journal of Engineering Research, Vol. 2, Issue 5, September- October 2012, pp.1236-1238.

[10]Leaching and mechanical behaviour of concrete manufacturedwith recycled aggregates D. Sani, G. Moriconi, G. Fava , V. Corinaldesi, Waste Management 25 (2005) 177-182.

[11] Merlet JD, Pimienta P - "Mechanical and physicochemical properties of concrete produced with coarse and fine recycled concrete aggregates", Proceedings of the Third International RILEM Symposium: Demolition and Reuse of Concrete and Masonry. Edition Lauritzen EK, Spon E \& FN, Odense, Denmark, October 1993.

[12]Parekh D. N \& Dr. Modhera C. D - "Assessment of recycled aggregate concrete", published in Journal of Engineering Research and Studies, March 2011.

[13] Properties of concretes produced with waste concrete aggregate,Ilker Bekir Topc_u*, Selim S_engel, Cement and Concrete Research 34 (2004) 1307-1312.

[14] Physical and mechanical properties of concretes produced with waste concrete, i.B. Topqu, Cement and Concrete Research, Vol. 27, No. 12, pp. 1817-1X23, 1997. 
[15] Pierre Matara, Rouba El Dalatib - "Strength of masonry blocks made with recycled concrete aggregates", published in Elsevier Journal, 2011.

[16] Pimienta.P, Tran.T, Delmotte.P, Colombard-Prout.M "Recycled aggregate used for making building blocks", Proceedings of the International Symposium: Sustainable Construction - Use of Recycled Concrete Aggregate. London, 11-12 November 1998.

[17] Recycling and reuse of waste concrete in China Part II. Structural behaviour of recycled aggregate concrete and engineering applications, Xuping Li , Resources, Conservation and Recycling 53 (2009) 107-112.

[18] Recycled aggregate concrete (RAC) methodology for estimating its long-term properties, Jorge de Brito \& Ricardo Robles (2010), INDIAN J. ENG. MATER. SCI., pp.449-462.

[19]S R Yadav \& S R Pathak - "Use Of Recycled Concrete Aggregate In Making Concrete", an Overview 34th Conference on our world in concrete \& structures, Singapore, 16 - 18 August 2009.

[20] Short and long-term behavior of structural concrete with recycled concrete aggregate S. Manzi , C. Mazzotti, M.C. Bignozzi.

[21] Tushar R Sonawane \& Prof. Dr. Sunil S Pimplikar "Use of Recycled Aggregate Concrete", published in IOSR Journal of Mechanical and Civil Engineering, June 2010.

[22] Use of aggregates from recycled construction and demolition waste in concrete, Akash Rao, Kumar N. Jha , Sudhir Misra, Resources, Conservation and Recycling 50 (2007) 71-81.

[23] Utilization of waste concrete powder as a substitution material for cement, Yong Jic Kim, Yun Wang Choi, Construction and Building Materials (2012) 500-504.

[24] Using waste concrete as aggregate,Ilker Bekir TOpCU and Nedim Fuat GUNCAN, Cement and Concrete Research, Vol. 25, No. 7. pp. 1385-1390.1995.

[25] Y P Gupta - "Use Of Recycled Aggregate in Concrete Construction a need for Sustainable Environment" 34th Conference on our world in concrete \& structures, Singapore, 16 - 18 August 2009. 